\title{
SWCS CONFERENCE Revisiting the 2016 SWCS International ECHOES Annual Conference
}

\author{
Jim Gulliford
}

$M$ any great cities of the world are located on the banks of similarly great rivers. Louisville, Kentucky, is no exception, ranking 30th in US population and established immediately upstream of the Falls of the Ohio River. It was here that early river travelers paused to contemplate the challenge of navigating the falls. It was here that more than 400 conservationists gathered for the 71st International Annual Conference of the Soil and Water Conservation Society (SWCS) to consider the challenge of "Managing Great River Landscapes." From the world's largest rivers to the smallest upstream landscape features, understanding the hydrology of and human influence on agricultural and urban landscapes is important to address the challenges of agricultural production, resource conservation, and environmental quality protection. This theme was the focus of this year's outstanding conference.

\section{PLENARY SESSIONS AND PANELS}

The conference began with the Fellows Forum, which examined the challenge of managing great rivers and the impact of those management decisions on urban and agricultural landscapes. Flood events on great rivers have profound impacts on communities and farms that exist in floodplains. Presentations described historic flood events on both the Ohio and Mississippi rivers, flood management plans that existed (or didn't exist), and the timing and effect of decisions made implementing those plans. Watch for a new book, Managing Mississippi and Ohio River Landscapes, by forum moderators Kenneth Olson and Lois Wright Morton that will be released by SWCS this year.

Our goal for each annual conference is to use the plenary sessions to inform, challenge, and inspire attendees. Chad Pregracke delivered this year's Pritchard Lecture to open the conference and delivered the goods as well. Observing the

Jim Gultiford is executive director of the Soil and Water Conservation Society, Ankeny, lowa. unsightly and toxic accumulation of trash in our rivers, he began a one-man crusade to clean America's rivers. He shared his story and conveyed the importance of each individual's contribution when faced with a great resource conservation challenge. If you missed Chad's presentation, take a moment to visit the Living Lands and Waters website (http://livinglandsandwaters.org/). You will gain an appreciation for the accomplishments they have achieved and see the parallel to the work that each of us contributes to soil and water conservation.

Day two featured two plenary panels. Nick Goeser returned for a third year with an update on the Soil Health Partnership. Joint presentations by farmers and their crop consultants provided insight into the agronomic and conservation relationship that is important as farmers commit to improving soil health. The second plenary examined the challenges conservation professionals have assisting farmers as they address impaired waters under the Clean Water Act. An important take-away message from this plenary was that conservation practice standards must be specific enough to address the water quality objective and flexible enough to fit into the specific landscape being farmed.

\section{CONSERVATION SCIENCE LEARNING, NETWORKING, AND RECOGNITION OPPORTUNITIES}

An important feature of the conference each year is the breadth of learning opportunities available to participants. Workshops provide in-depth training; tours provide access to unique, local conservation activities; and poster presentations provide an opportunity for one-on-one interaction between students, scientists, and participants regarding specific research or project activities. The exhibit hall offers agribusiness, agency, and conservation organizations a space to connect with participants and share their products, services, and education materials. All of these activities make the conference

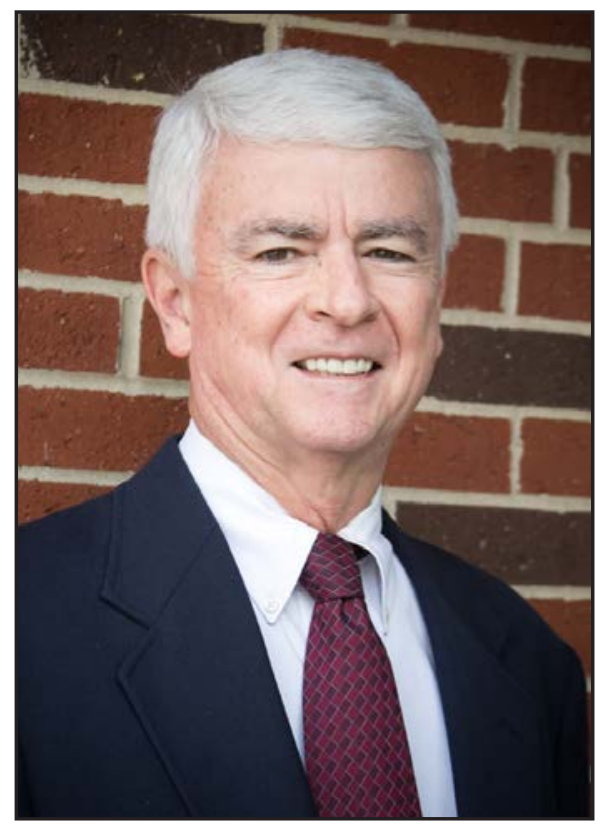

Jim Gulliford

a complete professional development and learning experience.

The Society recognized Jerry Hatfield as this year's recipient of the Hugh Hammond Bennett Award and conferred the honor of SWCS Fellow upon Kenneth Olson. The Hoosier, North Dakota, Michigan, and Hugh Hammond Bennett Chapters were recognized for their accomplishments and sustained conservation performance. Individuals were recognized for their conservation achievements, Journal of Soil and Water Conservation contributions, and SWCS leadership. USDA Natural Resources Conservation Service (NRCS) Chief Jason Weller addressed the Awards Luncheon and spoke to the challenge and importance of conservation planning and voluntary conservation service to farmers and ranchers. His presentation added important emphasis to the Tuesday plenary presentations on soil health and water quality challenges.

The Society's first photo contest was a smashing success! Initial entrees were screened to a final set of 10-all of which could have been winners. In the end, conference voting resulted in a first place tie. The winning photos can be seen on the SWCS conference website, and watch 
future Journal covers as you may see some of the entries there as well.

The annual conference also provides an opportunity for SWCS partner organizations to "piggyback" their activities around or during the conference. This year, the NRCS Conservation Innovation Grant (CIG) program featured six project presentations. Over the years, the CIG program has matured into an excellent locally led, "science to practice" opportunity for conservation districts and organizations to test their creative approaches to conservation challenges. A second organization that joins us each year for a luncheon and business meeting is the Association of Retired Conservation Service Employees. These individuals may be retired, but they have not lost their passion for conservation and the Society. They enjoy fellowship with each other but also engage the conference with their views.

\section{PARTICIPANT-DRIVEN SUCCESS}

Finally, it is important to understand that there are two essential elements to a successful conference: you must have a great program and a great participating audience. Special thanks are due to many individuals and organizations for their contributions. Deanna Osmond chaired the program committee that built the conference around its theme. The Kentucky Bluegrass Chapter members were remarkable hosts. They arranged tours, made us all feel welcome, and by my observation had the most fun of all our participants. The contributions of Syngenta and all of our sponsors and exhibitors helped us engage agriculture and agribusiness as conservation partners, and made our networking events successful. And again, the most important contributions came from the more than 400 conference participants from 46 states; Washington, DC; 4 Canadian Provinces; 6 additional countries; Guam; and Puerto Rico. These individuals contributed more than 150 presentations in workshops, symposia, individual presentations, and posters. This audience diversity brought a richness to the program, conversation, and networking that is only experienced by conference participants.

In closing, I can report that plans are well underway for next year's conference, which will be held July 30 through August 2, 2017, in Madison, Wisconsin. Watch the Society website this fall for a call for abstracts and conference arrangements. Plan now to bring your conservation voice to Madison. 